\title{
Article \\ Could Modifying the Skin Microbiome, Diet, and Lifestyle Help with the Adverse Skin Effects after Stopping Long-Term Topical Steroid Use?
}

\author{
Christopher Wallen-Russell ${ }^{1, *} \mathbb{B}$, Anja Gijsberts-Veens ${ }^{2,3,+}$ and Samuel Wallen-Russell ${ }^{1}$ \\ 1 Pavane Research Centre, Reading, Berkshire RG1 4QD, UK; sam@pavane.co.uk \\ 2 The Microbiome Centre, 2711 Zoetmeer, The Netherlands; info@anja-gijsberts.nl \\ 3 Practice for Functional Medicine, 6582 Heumen, The Netherlands \\ * Correspondence: kit@pavane.co.uk \\ + Official website of The Microbiome Centre: https://microbiome-center.nl/en/.
}

check for

updates

Citation: Wallen-Russell, C.;

Gijsberts-Veens, A.; Wallen-Russell, S.

Could Modifying the Skin

Microbiome, Diet, and Lifestyle Help with the Adverse Skin Effects after Stopping Long-Term Topical Steroid Use? Allergies 2022, 2, 1. https:// doi.org/10.3390/allergies2010001

Academic Editor: Enzo Berardesca

Received: 3 September 2021

Accepted: 1 December 2021

Published: 24 December 2021

Publisher's Note: MDPI stays neutral with regard to jurisdictional claims in published maps and institutional affiliations.

Copyright: (C) 2021 by the authors. Licensee MDPI, Basel, Switzerland. This article is an open access article distributed under the terms and conditions of the Creative Commons Attribution (CC BY) license (https:// creativecommons.org/licenses/by/ $4.0 /)$

\begin{abstract}
We set up this preliminary study to begin to evaluate one main question: could strengthening the microbiome have potential benefits for the skin condition of patients suffering with adverse effects after stopping long-term topical steroid use? We aim to turn it into a much larger study if the results show the interventions might help. After commonly being prescribed for eczema, cessation of topical steroid use, especially after long periods of inappropriate use, can leave lasting adverse effects on the body and skin, known by some as topical steroid withdrawal (TSW). This preliminary study involved seven human participants suffering with skin problems associated with TSW who approached Dr. Anja Gijsberts-Veens of their own volition because they were interested in more natural recovery methods. Five completed the study in full. Progress in skin condition was tracked by self-assessed symptom severity questionnaires filled out at the beginning and end of the five-month study. The skin microbiome was addressed by using a $100 \%$ natural product shown in previous work to significantly increase skin microbiome biodiversity. Three participants implemented dietary changes and supplementation in response to guidance after fecal sample analysis, with the aim of improving gut microbiome health. The average improvement in skin symptoms for all participants was $40 \%$, and average symptom improvement ranged from $14 \%$ for Patient 5 to $92 \%$ for Patient 1 . On average, the participants saw an improvement in $85 \%$ of their symptoms and stagnation or regression in $11 \%$ and $4 \%$, respectively. Our results suggest that the interventions used might improve the skin condition of TSW patients, but the small sample size and the lack of a control group mean that more definitive conclusions should be reserved for our follow-up work, which addresses these issues. We also aim to swab the skin of participants to assess the effect on the skin microbiome from skin and gut treatments, as well as including a more in-depth analysis of skin and gut microbiomes.
\end{abstract}

Keywords: topical steroid withdrawal; topical steroids; eczema; atopic dermatitis; skin microbiome; gut microbiome; microbiome; biodiversity; skin allergy epidemic

\section{Introduction}

This preliminary study was motivated by one main question: could strengthening the microbiome have potential benefits for the skin condition of people suffering with adverse effects after stopping long-term topical steroid use? If the results from this very small sample group suggest it might, we aim to expand the study to use a larger sample size and a control group to allow us to draw more reliable conclusions. This study is very small and will only be used to justify the possibility of larger follow-up work, so the results are not definitive. We also aim to perform more in-depth analyses such as sequencing the skin microbiome of participants and a full gut microbiome analysis, which were beyond the remit of this study. A small cohort of seven patients was recruited who were suffering with symptoms commonly associated with topical steroid withdrawal (TSW), after having 
stopped the long-term use of topical steroids. The treatment was split into two parts: skin and gut microbiome. For the gut microbiome, dietary changes were implemented following advice from Dr. Anja Gijsberts-Veens after a gut microbiome analysis was performed by taking fecal samples. Additionally, all five participants who completed the study used a $100 \%$ natural cosmetics product, shown to significantly increase the biodiversity of the skin microbiome [1], on their skin for 5 months. To investigate the effect of these interventions, a symptoms questionnaire was given to them at the beginning and the end of the 6-month study.

This study was believed to be important due to the prevalence of eczema continuing to rise at an alarming rate in the western world [2]. It is important to find ways of helping those with severe eczema and TSW, especially as this problem could become even more prevalent after a year of altered lifestyles due to the COVID-19 pandemic [3]. Eczema and TSW are both believed to be from alterations to the immune system, and so harnessing the microbiome may emerge as one of the most promising areas to treat them.

A damaged microbiome, low in biodiversity [4], has been linked to the majority of common skin problems, including eczema $[5,6]$, and the rise in chronic allergies in the western world [7]. Sufferers of atopic dermatitis also suffer from systemic problems such as food allergies, asthma, and allergic rhinitis [8]. As an integral part of the immune system, the microbiome is now thought to be crucial for protecting against whole-body systemic problems, not just those in the immediate vicinity of the skin or gut [9-12]. It is for this reason that treating the skin and gut microbiome together could pose a treatment for such issues.

Methods of treatment for chronic skin conditions such as eczema and psoriasis so far have been centered on the use of topical steroids [13]. At their inception around 60 years ago, they were a breakthrough for treating dermatoses due to their immunosuppressive and anti-inflammatory effects $[14,15]$. This introduction of modern medicine and drugs has transformed global health in a way unparalleled in human history.

However, there is a growing challenge: the overuse of potent drugs intended only for acute illnesses and short-term use, where they are used for long-term, chronic conditions $[16,17]$. Medical guidelines state that very high potency topical steroids should not be used for more than three weeks continuously $[18,19]$. Despite managing the symptoms very effectively in the short term, and helping many people with severe skin problems get on with their daily lives, long-term and inappropriate use of high potency versions can lead to worrying adverse effects [14].

Partly due to the rise of reports of the condition on social media, studies, including one by the National Eczema Association, have confirmed that discontinuation after overuse can result in whole-body problems [20]. This is often called topical steroid withdrawal (TSW), or red burning skin syndrome (RBSS) [21-23]. These can last for long periods of time and cause significant psychological distress [24]. The mechanisms and reasons are not fully understood, but many factors are thought to contribute [22]. Topical symptoms include widespread red, sensitive skin, oozing sores, bone-deep itch, and 'elephant-like' looking skin $[23,25-27]$. Although it is often not accepted as a condition in the medical profession, in this study, we refer to the short-term adverse effects and the long-term damage left behind as TSW.

\section{Materials and Methods}

This preliminary study investigated seven human volunteers who came to Dr. Anja Gijsberts-Veens of their own volition due to her status as a doctor of functional medicine. They did not want to continue topical steroid use and were interested in investigating more natural ways of helping their bodies recover. Each participant had suffered with eczema before using topical steroids on their skin over long periods of time; this ranged from 15 to 48 years. All the patients had made the decision to stop using topical steroids themselves and had reported a regression in their skin condition that showed symptoms associated with TSW. Six were women, and one was a man. We note that only Patients 1-5 finished 
the skin microbiome stipulations for the study and completed the final questionnaire. The participants were made aware of the conditions for the study at the beginning. The participants were required to fill out a questionnaire at the start and end of the study to keep track of the change in symptoms and their severity on the skin.

All participants provided verbal consent prior to enrollment in the study. Results and data from this study cannot be linked to a certain individual due to anonymous reporting and data handling. The process was agreed on by Dr. Anja Gijsberts-Veens of the Microbiome Centre and the Centre for Functional Medicine, the Netherlands.

\subsection{Gut Microbiome Intervention}

The gut microbiome of the participants was addressed under the supervision of Dr. Anja Gijsberts-Veens. Patients 3, 4, and 7 had their gut microbiome analyzed by taking a fecal sample; the laboratory work was done by BIOVIS, and the Microbiome Centre in the Netherlands wrote up a report using the data and created individualized probiotic supplements to help the gut microbiome of the patients who opted for it. The following were included in the report: species, diversity, dysbiosis index, $\mathrm{pH}$, digestion (of sugar, fat, proteins), zonulin (used as a biomarker of impaired gut barrier function for certain diseases [28]), inflammation markers (calprotectin, alpha 1 antitrypsin), and secretory IgA.

The results of the fecal analyses and advice for each participant who opted for it are shown in the Supplementary File S1. The advice from Dr. Anja Gijsberts-Veens is available on request from the authors. A gut microbiome analysis was not performed again at the end of the study after the skin and gut interventions. It was beyond the remit of this study to perform a full gut microbiome analysis; if the results of this study show promise, this will be done in future work. For this reason, the sample collection, DNA extraction, and analysis methodology are included in Appendix A, as they are not the main focus of this study.

Human fecal microbiome samples were taken noninvasively and handled with approval by and in accordance with the professionals at BIOVIS and the Microbiome Centre in the Netherlands. They stated that no ethical concerns were raised by the methods applied and approved the procedures in this study. Informed verbal consent was obtained from each person prior to the study. Samples were treated anonymously, and human material was not the focus point of this study. Microbial samples or data derived cannot be linked to a certain individual. The process of the experimentation was agreed upon by Dr. Anja Gijsberts-Veens, the Microbiome Centre, and BIOVIS.

Dietary and lifestyle changes were then implemented depending on the results of the microbiome analysis, along with the use of personalized probiotics. The changes implemented were done with the goal of increasing gut microbiome biodiversity, which has been shown to positively impact the skin [11,29]. In our 2017 work, we noticed that biodiversity is the only current reliable indicator of ecosystem health $[7,30-36]$. This was inspired by research that found the healthiest gut ever recorded in infants in Burkina Faso who displayed 'unprecedented' levels of diversity [37]. Previous work has postulated that probiotics are implemented incorrectly without personalization [38]. The dietary advice consisted mainly of cutting out inflammation-inducing foods, including lots of sugar, processed foods, coffee, and alcohol; increasing the amount of pure, unprocessed, organic, and diverse whole foods; and drinking plenty of water. The lifestyle changes included a mindset shift towards a long-term lifestyle change, rather than a quick-fix solution. In addition, exercise, sun, time in nature, meditation, and a positive attitude were advised.

\subsection{Skin Microbiome Intervention}

The products used to address the skin microbiome were a 100\% natural face and body wash shown to significantly increase skin microbiome biodiversity [1]. All information on the product can be found in our previous work, where we investigated its effect on the skin microbiome of human participants [1]. The guidelines for use of the product for the skin are listed below: 
- Use the product on the skin at least $1 \times$ per day for a minimum of 4 months.

- To use the product, mix with a small amount of water to form a solution, and gently massage onto the body.

- Use no other cosmetics products and try to stick to this as rigidly as possible. Exemptions in extreme cases, or where it was unavoidable were allowed, e.g., wearing some makeup for an important business meeting.

- In the beginning, introduce the product slowly to the body by using it mixed with a small quantity of water once every couple of days, and slowly build up to using it $1 \times$ per day by the end of the first month.

\subsection{Data Analysis}

The participants were asked to fill out a questionnaire on their symptoms the day before they started the microbiome strengthening plan and as soon as they finished. It asked them to rate the severity of each symptom they were experiencing by giving them a number out of ten. Zero meant the symptom was nonexistent, and ten meant it was the worst possible. Microsoft Excel was used to turn the answers into the symptom severity graphs in Section 3.2.

We also performed bivariate linear correlation analysis on some of the variables in this study using the Pearson correlation coefficient method [39,40] to investigate whether a relationship existed between the amount of time topical steroids was taken and the average improvement of symptoms. We did the same for time elapsed between stopping the use of topical steroids and the start of the study and the average improvement in symptoms.

Microsoft Excel was used to calculate the Pearson correlation coefficient, or ' $r$ ' number. If this number exceeds $r_{\text {req, }}$ or $p$, a statistically significant correlation can be reported. This is calculated using the table of correlation coefficients displayed in Table 1 [41], where $r_{\text {req }}$, or $p$, needed for correlation is shown at different degrees of freedom and probability levels. This table was turned into the graph shown in Figure 1, where a formula for $r_{\text {req }}$ was obtained. 'Degrees of Freedom' is the number of data points on any given graph, minus two. Therefore, for this study, the ' $r$ ' number required to statistically show a correlation $r_{\text {req }}=0.807$ at the $p=0.05$ level because there are five participants. The working is displayed below.

$$
\begin{gathered}
y=-0.196 \ln (x)+1.0219 \\
y=-0.196 \ln (3)+1.0219 \\
r_{\text {req }}=0.807
\end{gathered}
$$

- $y=r_{\text {req }}$ or $p$;

- $x=$ degrees of freedom.

Table 1. Table of correlation coefficients at varying degrees of freedom.

\begin{tabular}{ccc}
\hline \multirow{2}{*}{ Degrees of Freedom } & \multicolumn{2}{c}{ Probability, $\boldsymbol{p}$} \\
\cline { 2 - 3 } & $\mathbf{0 . 0 5}$ & $\mathbf{0 . 0 1}$ \\
\hline 1 & 0.997 & 1 \\
5 & 0.755 & 0.875 \\
10 & 0.576 & 0.708 \\
15 & 0.482 & 0.606 \\
20 & 0.423 & 0.457 \\
25 & 0.381 & 0.487 \\
30 & 0.349 & 0.449 \\
90 & 0.205 & 0.267 \\
100 & 0.195 & 0.254 \\
\hline
\end{tabular}




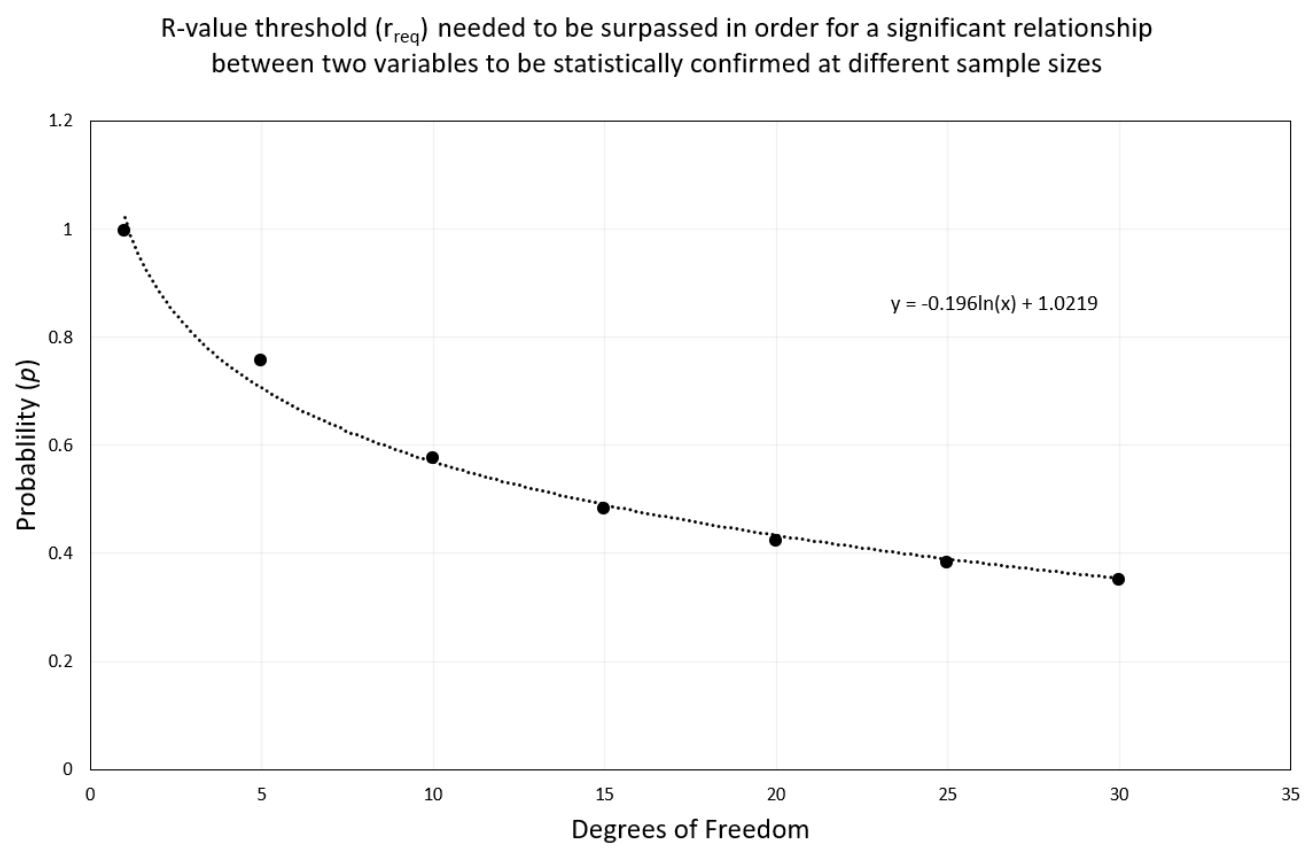

Figure 1. Graph showing $r_{\text {req, }}$, or $p$, probability needed for the correlation coefficient, $r$, to be equal or more than for a statistically significant correlation to be observed.

\section{Results}

\subsection{Participant Information}

Table 2 collates the important information regarding each participant involved in the study.

Table 2. Participant information.

\begin{tabular}{cccccccc}
\hline $\begin{array}{c}\text { Patient } \\
\text { Number }\end{array}$ & Sex & $\begin{array}{c}\text { Time Topical } \\
\text { Steroids Taken } \\
\text { For (Yrs) }\end{array}$ & $\begin{array}{c}\text { Time TSW } \\
\text { (Years) }\end{array}$ & $\begin{array}{c}\text { Initial Skin } \\
\text { Problem(s) }\end{array}$ & Other Drugs & $\begin{array}{c}\text { Other Health } \\
\text { Issues }\end{array}$ & $\begin{array}{c}\text { Completed } \\
\text { Study? }\end{array}$ \\
\hline 1 & F & 48 & 4.5 & Eczema as a baby & - & Yes \\
\hline 2 & F & 35 & 4.5 & $\begin{array}{c}\text { Eczema when she } \\
\text { was born }\end{array}$ & $\begin{array}{c}\text { Antibiotics, } \\
\text { Antifungal Creams }\end{array}$ & $\begin{array}{c}\text { Pregnant, food, } \\
\text { dust mites, and } \\
\text { pollen allergies }\end{array}$ \\
\hline 3 & F & 20 & 0.019 & Eczema 20+ years & - & Food allergies & Yes \\
\hline 4 & F & 15 & 1.8 & Eczema as a baby & - & Food allergies & Yes \\
\hline 5 & F & 20 & 4.5 & Eczema for $18+$ & Ventolin/Salbutamol & Asthma & Yes \\
\hline 6 & F & - & - & Eczema & Unknown & & No \\
\hline 7 & M & - & - & Eczema & - & & No \\
\hline
\end{tabular}

\subsection{Skin Condition}

The participants were required to fill out a questionnaire on the symptoms of their skin at the beginning and end of the study. They were asked to give each symptom a score out of ten based on the severity, with ten being the worst possible, and zero meaning nonexistent. Figure $2 \mathrm{~A}-\mathrm{E}$ shows the severity of symptoms before and after the study for Patient 1, 2, 3, 4, and 5 respectively. Figure 2F shows each participant's average percentage improvement in symptoms, along with the overall average, which was $+40 \%$. Figure 3 shows the percentage of symptoms that improved, regressed or did not improve for all participants. Tables 3-7 show the percentage improvement for Patient 1 to Patient 5. 
(A)

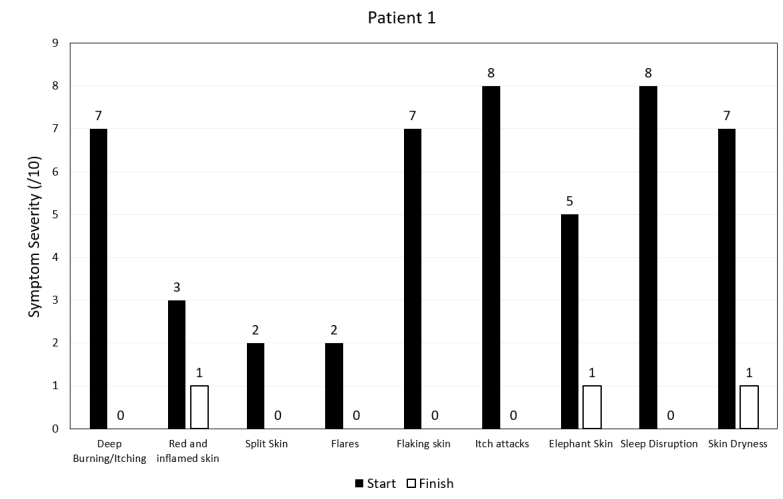

(D)

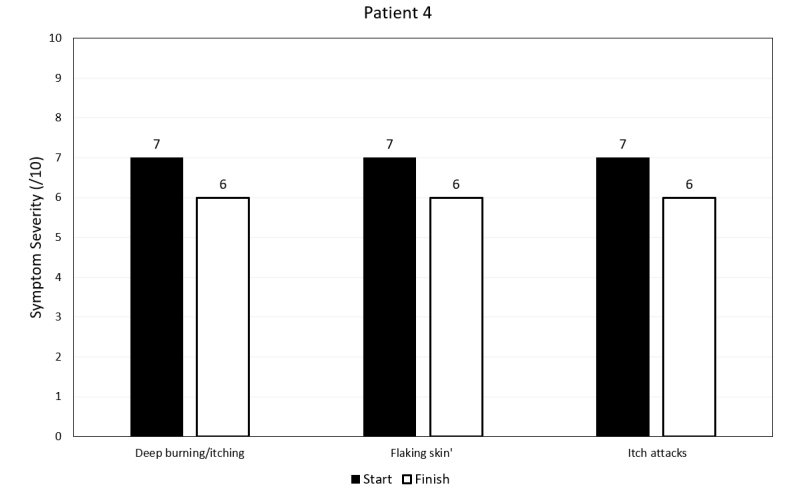

(B)

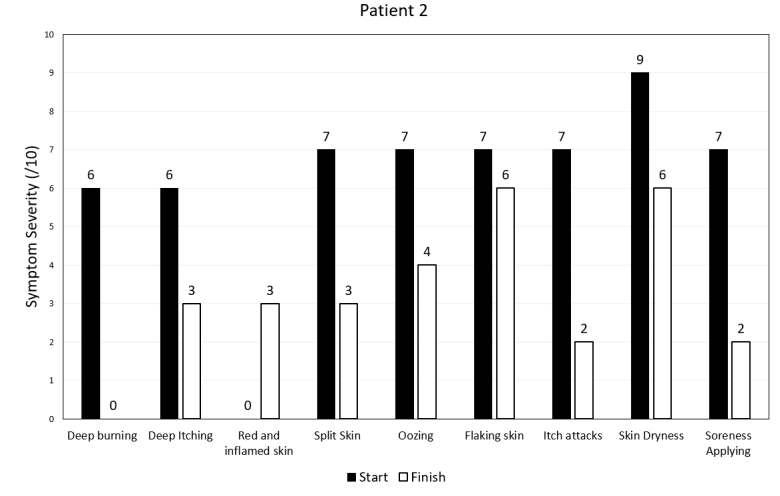

(E)

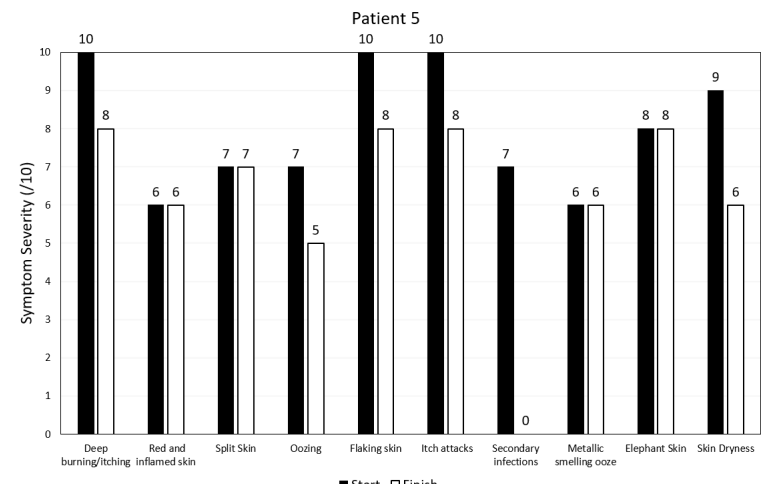

(C)

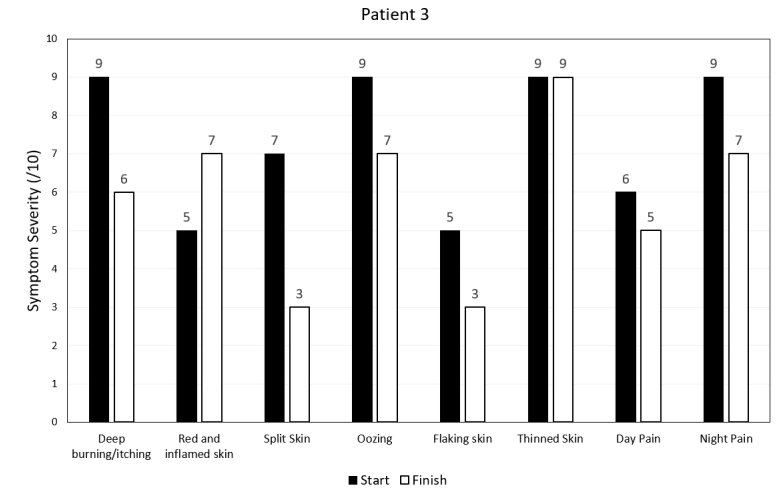

(F)

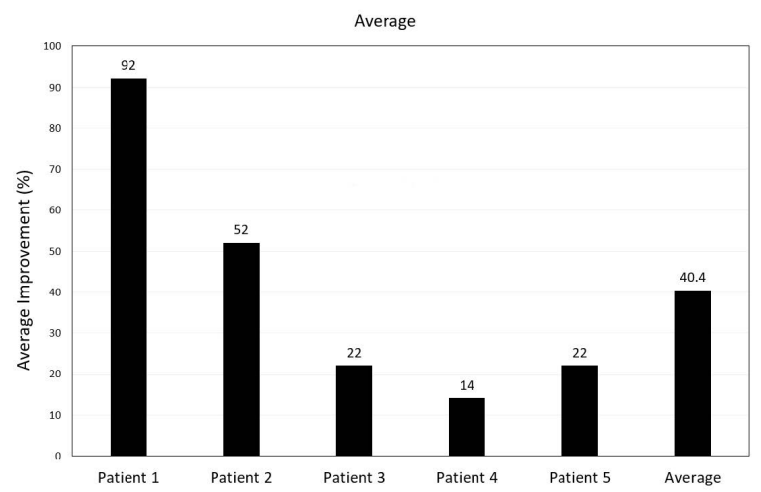

Figure 2. Change in severity of symptoms seen by the participants. The bars in black show the severity of each symptom at the start of the study, and the bars in white show the severity at the end of the study. Severity was measured in a self-assessed value out of ten, where ten was the worst possible. Graph (A) is Patient 1 , Graph (B) shows Patient 2, Graph (C) shows Patient 3, Graph (D) shows Patient 4, Graph (E) shows Patient 5, and Graph (F) shows the average percentage change in symptom severity for each participant. A positive percentage indicates an improvement, and a negative percentage change indicates a worsening of symptoms. 


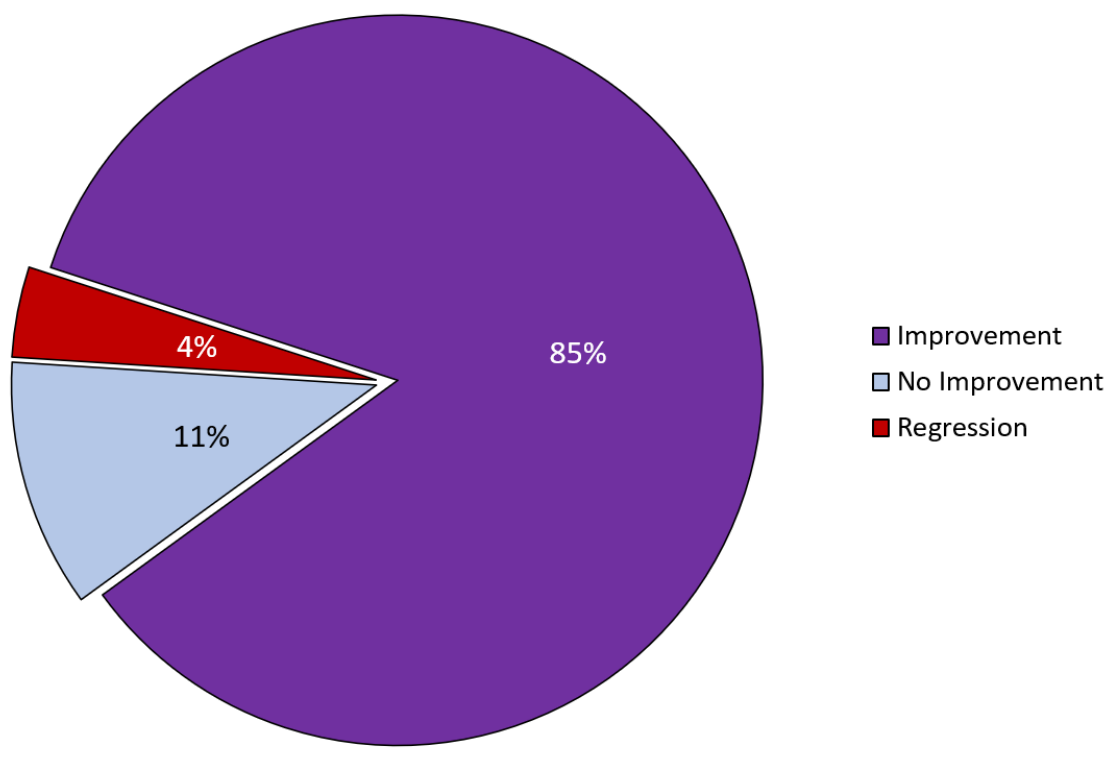

Figure 3. Percentage of symptoms that improved, regressed, or did not improve. This was done as a total of all the symptoms that the patients who finished the study (1-5) were dealing with.

Table 3. Severity scores for Patient 1 before and after completing the study. The numbers in the table are out of ten, with ten being the worst severity, and zero meaning the symptom has ceased to exist. The percentage change in the severity of each symptom is shown in the bottom row.

\begin{tabular}{|c|c|c|c|c|c|c|c|c|c|c|}
\hline \multicolumn{11}{|c|}{ Patient 1} \\
\hline & $\begin{array}{l}\text { Deep Burn- } \\
\text { ing/Itching }\end{array}$ & $\begin{array}{l}\text { Split } \\
\text { Skin }\end{array}$ & Flares & $\begin{array}{l}\text { Flaking } \\
\text { Skin }\end{array}$ & $\begin{array}{c}\text { Itch } \\
\text { Attacks }\end{array}$ & $\begin{array}{c}\text { Sleep } \\
\text { Disruption }\end{array}$ & $\begin{array}{c}\text { Skin } \\
\text { Dryness }\end{array}$ & $\begin{array}{c}\text { Red and } \\
\text { Inflamed Skin }\end{array}$ & $\begin{array}{l}\text { Elephant } \\
\text { Skin }\end{array}$ & Average \\
\hline Before & 7 & 2 & 2 & 7 & 8 & 8 & 7 & 3 & 5 & \\
\hline After & 0 & 0 & 0 & 0 & 0 & 0 & 1 & 1 & 1 & \\
\hline $\begin{array}{c}\% \\
\text { Change }\end{array}$ & $100 \%$ & $100 \%$ & $100 \%$ & $100 \%$ & $100 \%$ & $100 \%$ & $86 \%$ & $67 \%$ & $80 \%$ & $92 \%$ \\
\hline
\end{tabular}

Table 4. Severity scores for Patient 2 before and after completing the study. The numbers in the table are out of ten, with ten being the worst severity, and zero meaning the symptom has ceased to exist. The percentage change in the severity of each symptom is shown in the bottom row.

\begin{tabular}{|c|c|c|c|c|c|c|c|c|c|c|}
\hline \multicolumn{11}{|c|}{ Patient 2} \\
\hline & $\begin{array}{c}\text { Deep } \\
\text { Burning }\end{array}$ & $\begin{array}{l}\text { Deep } \\
\text { Itching }\end{array}$ & $\begin{array}{c}\text { Red and } \\
\text { Inflamed Skin }\end{array}$ & $\begin{array}{l}\text { Split } \\
\text { Skin }\end{array}$ & Oozing & $\begin{array}{l}\text { Flaking } \\
\text { Skin }\end{array}$ & $\begin{array}{c}\text { Itch } \\
\text { Attacks }\end{array}$ & $\begin{array}{c}\text { Skin } \\
\text { Dryness }\end{array}$ & $\begin{array}{l}\text { Soreness } \\
\text { Applying }\end{array}$ & Average \\
\hline Before & 6 & 6 & 0 & 7 & 7 & 7 & 7 & 9 & 7 & \\
\hline After & 0 & 3 & 3 & 3 & 4 & 6 & 2 & 6 & 2 & \\
\hline $\begin{array}{c}\% \\
\text { Change }\end{array}$ & $100 \%$ & $50 \%$ & $30 \%$ & $57 \%$ & $43 \%$ & $14 \%$ & $71 \%$ & $33 \%$ & $71 \%$ & $52 \%$ \\
\hline
\end{tabular}

Table 5. Severity scores for Patient 3 before and after completing the study. The numbers in the table are out of ten, with ten being the worst severity, and zero meaning the symptom has ceased to exist. The percentage change in the severity of each symptom is shown in the bottom row.

\begin{tabular}{|c|c|c|c|c|c|c|c|c|}
\hline \multicolumn{9}{|c|}{ Patient 3} \\
\hline & $\begin{array}{l}\text { Deep Burn- } \\
\text { ing/Itching }\end{array}$ & $\begin{array}{c}\text { Red and } \\
\text { Inflamed Skin }\end{array}$ & $\begin{array}{l}\text { Split } \\
\text { Skin }\end{array}$ & Oozing & Flaking Skin & Thinned Skin & Day Pain & Night Pain \\
\hline Before & 9 & 5 & 7 & 9 & 5 & 9 & 6 & 9 \\
\hline After & 6 & 7 & 3 & 7 & 3 & 9 & 5 & 7 \\
\hline$\%$ Change & $33 \%$ & $-40 \%$ & $57 \%$ & $22 \%$ & $40 \%$ & $0 \%$ & $17 \%$ & $22 \%$ \\
\hline
\end{tabular}


Table 6. Severity scores for Patient 4 before and after completing the study. The numbers in the table are out of ten, with ten being the worst severity, and zero meaning the symptom has ceased to exist. The percentage change in the severity of each symptom is shown in the bottom row.

\begin{tabular}{cccc}
\hline & \multicolumn{4}{c}{ Patient 4 } & Flaking Skin & Itch Attacks & 7 \\
\hline Before & Deep Burning/Itching & 7 & 6 \\
\hline After & 7 & 6 & $14 \%$ \\
\hline Change & 6 & $14 \%$ & $14 \%$ \\
\hline
\end{tabular}

Table 7. Severity scores for Patient 5 before and after completing the study. The numbers in the table are out of ten, with ten being the worst severity, and zero meaning the symptom has ceased to exist. The percentage change in the severity of each symptom is shown in the bottom row.

\begin{tabular}{|c|c|c|c|c|c|c|c|c|c|c|c|}
\hline \multicolumn{12}{|c|}{ Patient 5} \\
\hline & $\begin{array}{l}\text { Deep Burn- } \\
\text { ing/Itching }\end{array}$ & $\begin{array}{l}\text { Red and } \\
\text { Inflamed } \\
\text { Skin }\end{array}$ & $\begin{array}{l}\text { Split } \\
\text { Skin }\end{array}$ & Oozing & $\begin{array}{l}\text { Flaking } \\
\text { Skin }\end{array}$ & $\begin{array}{c}\text { Itch } \\
\text { Attacks }\end{array}$ & $\begin{array}{l}\text { Secondary } \\
\text { Infections }\end{array}$ & $\begin{array}{l}\text { Metallic } \\
\text { Smelling } \\
\text { Ooze }\end{array}$ & $\begin{array}{l}\text { Elephant } \\
\text { Skin }\end{array}$ & $\begin{array}{c}\text { Skin } \\
\text { Dryness }\end{array}$ & Avg \\
\hline Before & 10 & 6 & 7 & 7 & 10 & 10 & 7 & 6 & 8 & 9 & - \\
\hline After & 8 & 6 & 7 & 5 & 8 & 8 & 0 & 6 & 8 & 6 & - \\
\hline $\begin{array}{c}\% \\
\text { Change }\end{array}$ & $20 \%$ & $0 \%$ & $0 \%$ & $29 \%$ & $20 \%$ & $20 \%$ & $100 \%$ & $0 \%$ & $0 \%$ & $33 \%$ & $22 \%$ \\
\hline
\end{tabular}

On average, the participants in this study saw an improvement in $85 \%$ of their symptoms, no change in $11 \%$ and $4 \%$ of symptoms regressed. Figure 3 shows this. The participants in this study had all used topical steroids regularly for 15 to 48 years, which puts them in the severe end of the spectrum.

We note Patient 2's pregnancy during the study could have done so, which turned out to be $49 \%$ on average. Pregnancy was shown to worsen the eczema in $75 \%$ of women who were previous sufferers and cause other skin problems [42,43]. Also commonly reported in previous TSW patients is the occurrence of secondary fungal or bacterial infections, which implies the microbiome is out of balance. Patient 2 used two courses of antifungal creams during the study, which could also have set back progress because the creams could kill off fungi that are important constituents of healthy skin, subsequently leaving the skin microbiome more damaged and open to infection.

Patient 3 had only stopped using topical steroids one week before starting the study. Previous work has shown that TSW symptoms appear days to weeks after discontinuation of topical steroid use [21]. Therefore, it is likely in this scenario that the symptoms could get worse in at least the first few weeks of the study, regardless of other factors.

\subsection{Correlation}

In Figure 4A, we plotted the length of time topical steroids were used by each participant against the average improvement in symptoms, which shows a statistically significant positive correlation $(r=0.98)$. The table in Figure $4 \mathrm{~B}$ shows the values used to create Figure 4A and the correlation coefficient, or ' $r$-number', between the variables. In Figure $4 \mathrm{C}$, we plotted the length of time between stopping steroids and starting the study against the average improvement in symptoms for each participant. There was no statistically significant correlation observed between these two variables $(r=0.57)$. The table shown in Figure 4D displays the values used to create the graph in Figure 4C and the correlation coefficient, or ' $r$-number', between the variables. The ' $p$-value' needed to be surpassed by $r$ for a statistically significant correlation to be seen was $p=0.8065$. The calculation of this was explained in Section 2.3 of the Materials and Methods. The sample 
size in this study is too small to use these results as definitive evidence that a relationship does or does not exist between these variables.

(A)

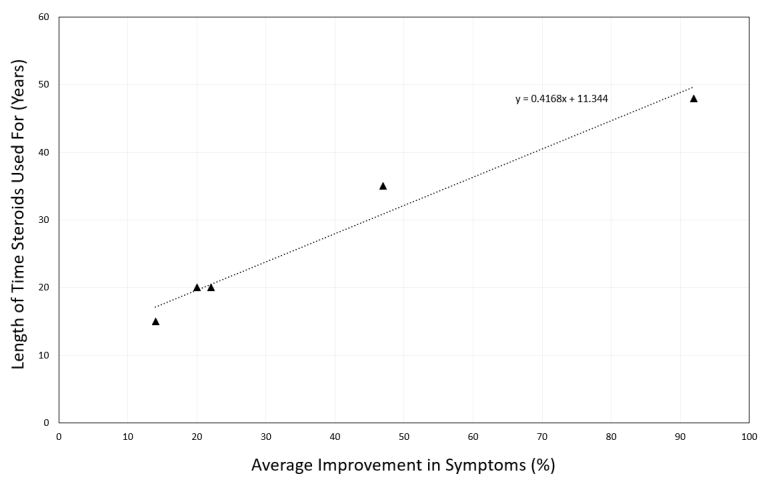

(B)

\begin{tabular}{cccc}
\hline Participant & Avg. Improvement (\%) & Time Using Steroids (Years) & ' $\mathbf{r}$ ' Value \\
\hline Patient 1 & 82 & 48 & - \\
Patient 2 & 49 & 35 & - \\
Patient 3 & 22 & 20 & - \\
Patient 4 & 15 & 15 & - \\
Patient 5 & 21 & 20 & - \\
Overall ' $r$ ' Value & - & - & 0.983 \\
\hline
\end{tabular}

(C)

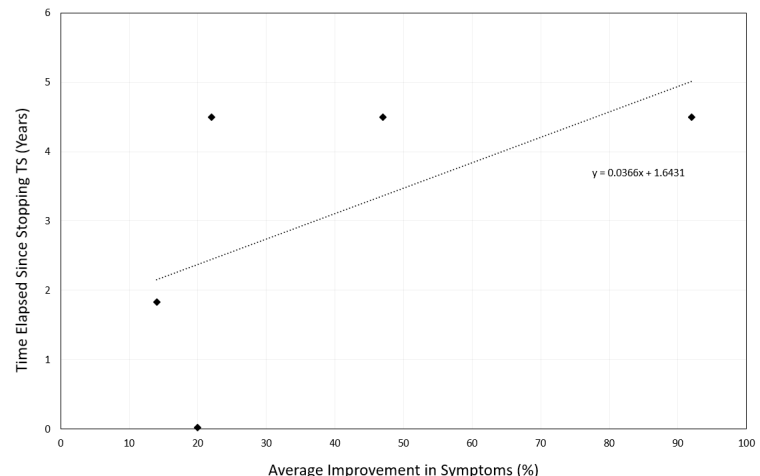

(D)

\begin{tabular}{cccc}
\hline Participant & Avg. Improvement (\%) & Time TSW (Years) & ' $\mathbf{r}$ ' Value \\
\hline Patient 1 & 82 & 4.5 & - \\
Patient 2 & 49 & 4.5 & - \\
Patient 3 & 22 & 0.019 & - \\
Patient 4 & 15 & 1.8 & - \\
Patient 5 & 21 & 4.5 & - \\
Overall ' $r$ ' Value & - & - & 0.572 \\
\hline
\end{tabular}

Figure 4. (A) Graph showing the length of time the participants used topical steroids for before quitting, against the average improvement in symptoms for the participants in this study $(r=0.98)$. (B) Table showing the figures used to create the graph in (A), including the correlation coefficient between the two variables, ' $r$ '. (C) Graph showing length of time elapsed between stopping the use of topical steroids and starting the study against the average improvement in symptoms for the patients. (D) Table showing the numbers used to create the graph in (C), including the correlation coefficient, ' $r$ ', between the two variables.

\section{Discussion}

The discussion is split into two parts to answer the questions posed in the Introduction (Section 1).

\subsection{Does Addressing the Microbiome Show Promise for Helping People Suffering with TSW?}

This study aimed to rebalance and increase the diversity of the microbiome. There appeared to be improvements in the participants' skin condition related to the interventions. We note that the use of five patients is too small to make conclusions with certainty and that an improvement in skin health could be influenced by other factors, including a reduction in exposure to synthetic ingredients and pollution in our western environment [1], time after quitting steroids [26], the seasons [44,45], exposure to the sun, and reduction in stress [46].

Therefore, we cannot be certain the microbiome interventions were major factors in skin condition improvement, but we can use certain indicators as a guide. Having used topical steroids for many years, Patients 1,2, 4, and 5 had come to a standstill with their skin condition, with their skin cycling with the seasons. The end point of the study was during the winter months when it is common for the skin condition to get worse for some people with severe eczema and TSW [44,45,47]. However, despite small, expected fluctuations, a large, exaggerated seasonal regression was not seen for these participants as it had been in previous years. For example, in the previous four years, Patient 1 had been through a cycle of skin improvement in the summer due to sun exposure and deterioration in the winter. During this study, this was not seen. In fact, the improvements continued throughout the winter, and some symptoms disappeared.

Could some improvements be due to time being the 'best healer'? Although our correlation analysis is inconclusive, it is a possibility; previous work suggested time is a 
factor, but the duration of topical steroid use was much shorter than this study [26,48]. We stress the importance of 'expectation management' when dealing with TSW. Previous work has shown even a few months of topical steroid use can result in years of damage left behind [26]. Symptoms can even get much worse within the first few months [21], so after suffering with TSW and eczema for many years with minimal improvement, even an improvement of $20 \%$ could signal positive signs. Rebuilding the microbiome will be a long-term process, not an overnight one, especially if the western environment is degrading it $[1,7]$.

The gut microbiome advice consisted of dietary improvements, supplementation, and ingesting personalized probiotic supplements, all of which have been shown in previous work to positively affect skin health [49-53]. In addition, cutting out certain 'triggering' foods was advised. This can reduce the severity of itching and burning, commonly associated with severe eczema and TSW [52,53]. However, this may manage symptoms more than solving the underlying problem.

The skin health product used in this study was shown to significantly increase skin microbiome diversity in previous work [1]. It is not a topical probiotic product; if implemented incorrectly, these could decrease skin microbiome biodiversity [38]. Instead, the product tries to create the right conditions on the skin for biodiversity to flourish [1,7]. As healthier skin is characterized by an increase in biodiversity [7], this intervention could also have influenced skin condition. A damaged skin microbiome, low in biodiversity, is linked to most common skin problems, including eczema [5,6], psoriasis [54], skin cancer [55], and many more [11,56-65]. Stopping or drastically reducing the use of other cosmetics containing synthetic ingredients was also an integral part of the skin microbiome plan. Studies have explained how exposure of the skin to 21st-century chemicals, such as those in modern cosmetics, steroids, and cosmetics, is thought to have contributed to skin microbiome damage $[1,7,66-74]$ and a large rise in allergies $[4,65,67,75-87]$.

\subsection{Are the Results Enough to Expand the Study in the Future?}

We believe these preliminary results imply an improvement in skin condition might be attained by using the interventions described, but because of the small sample size and lack of a control group, it should be investigated more thoroughly in future work. The use of a control group will aim to minimize the effect of placebo and other factors. A much larger sample group will allow us to investigate whether the improvements in this study are anomalous and will help us to make predictions of the microbiome's potential for helping similar conditions with more confidence. To thoroughly investigate the effect of the described microbiome interventions, we will take skin swab samples from the participants to assess any changes to the skin microbiome, primarily in biodiversity, by sequencing the skin's microbes before and after the study. To do this, we will use our discovery of the 'first reliable skin health measuring mechanism', recently updated [4], where a relative increase in microbial biodiversity is associated with healthier skin [7]. We will also conduct an in-depth analysis of the gut microbiome before and after the study, analyzing primarily the change in biodiversity.

We should also run correlation analysis on the variables to see if any relationships exist, including both Pearson $[39,40]$ and Spearman rho methods $[39,88]$, preceded by a Shapiro-Wilk normality test [89-91].

It is well known that a gut-skin axis exists [49,92-94], but often researchers and medical practitioners underestimate the influence of the skin microbiome on the gut. For example, as the body's first line of defense, a damaged skin microbiome could be a major cause of food allergies $[8,11,95]$. We believe that addressing both skin and gut microbiomes simultaneously may impact whole-body health more than addressing either in isolation. Therefore, we will observe effects on both gut and skin. 


\section{Conclusions}

This small, preliminary study explored the idea of using the skin and gut microbiome for helping people suffering with severe skin problems after the long-term use of topical steroids, initially prescribed for eczema. Techniques shown to improve the skin and gut microbiome were used with the aim of creating the right environment for a healthy diversity of microbes to thrive. The average symptom change of all five participants who finished the study was $+40 \%$, and the individual averages ranged from $+14 \%$ to $+92 \%$. On average, $75 \%$ of symptoms improved, $11 \%$ stayed the same, and $4 \%$ got worse. Partly because the study ended during the winter months when skin health normally deteriorates, we believe these preliminary results suggest that the interventions used might improve the skin condition of TSW patients, but the small sample size and the lack of a control group mean that more definitive conclusions should be reserved for our follow-up work, which addresses these issues. We will also sequence the skin microbiome of participants to see if changes in skin condition are linked to changes in diversity and alterations in the microbial community. Future studies on this topic are increasingly important, especially as eczema prevalence is rising quickly among adolescents, even before the COVID-19 pandemic.

Supplementary Materials: The following are available online at https: / www.mdpi.com/article / 10.3390/allergies2010001/s1, Supplementary File S1: Gut microbiome analyses and corresponding advice for all patients who opted for it (Patients 3, 4, \& 7).

Author Contributions: Conceptualization, C.W.-R., A.G.-V. and S.W.-R.; methodology, C.W.-R. and A.G.-V.; validation, A.G.-V.; formal analysis, C.W.-R. and S.W.-R.; investigation, C.W.-R., A.G.-V. and S.W.-R.; resources, A.G.-V.; writing-original draft preparation, C.W.-R. and S.W.-R.; writing-review and editing, C.W.-R., S.W.-R. and A.G.-V.; visualization, C.W.-R., S.W.-R. and A.G.-V.; supervision, C.W.-R. and A.G.-V.; project administration, C.W.-R. and A.G.-V. All authors have read and agreed to the published version of the manuscript.

Funding: This research received no external funding.

Institutional Review Board Statement: The Microbiome Centre stated that no ethical concerns were raised by the methods applied and approved the procedures used in this study.

Informed Consent Statement: Informed consent was obtained from all subjects involved in the study.

Data Availability Statement: The data presented in this study are available on request from the corresponding author. The data are not publicly available due to privacy issues.

Acknowledgments: We would like to thank Linda Russell and Nick Wallen for their support, without whom our work would not be possible. BIOVIS and the Microbiome Centre in the Netherlands also deserve special mention for their work on gut microbiome analyses and advice. We would also like to mention that we used the library and information services of University College London (UCL) and the University of Notre Dame, where the authors were alumni and researchers, respectively.

Conflicts of Interest: Christopher Wallen-Russell and Sam Wallen-Russell are employees of research and development company Pavane Consultants Ltd., and directors of JooMo Ltd. As license holder for the JooMo Ltd. range of skin health products, Pavane Consultants Ltd. is interested in determining how skin health can be measured and which environmental factors have caused the huge increase in skin allergy problems in the past 75 years. The company has no role in the design of the study; in the collection, analyses, or interpretation of data; in the writing of the manuscript, or in the decision to publish the results. All other authors declare no conflict of interest.

\section{Appendix A. Gut Microbiome: Sample Collection, DNA Extraction and Analysis}

This section details the methods used by BIOVIS which will be used more in the followup, larger study. For the participants who opted for gut microbiome analysis, a fecal sample was collected in a clean container and then sent to the BIOVIS laboratories. To provide for anaerobic conditions within the container, they were filled to at least 50\% [96]. Because stool samples must be fresh, otherwise they do not reflect the microbial communities of the gut, they were analyzed within two days of being taken. 
In the microbiome analysis, a region encompassing the V3 and V4 hypervariable regions of the 16S rRNA gene is targeted for sequencing, utilizing the Illumina MiSeq instrument. The sequence information of the sequenced regions enabled taxonomic classification of microbial communities from stool specimens collected within the study.

For sequence library preparation, primers were designed that contain an overhang adapter sequence, index sequence, spacer sequence, and the locus-specific sequence of the V3 and V4 regions. Bacterial genomic DNA extracted from stool specimens was amplified, fluorimetrically quantified and normalized, indexed (barcoded) for sequencing using the Nextera XT DNA Library Preparation Kit (Illumina, Eindhoven, the Netherlands), and pooled prior to sequencing on the MiSeq platform. The amplicon pools were prepared for sequencing with MagSi-NGSPREP Plus-Magnetic Beads for NGS (MagnaMedics $\mathrm{GmbH}$, Aachen, Germany), and the size and quantity of the amplicon library was assessed via the Quant-iT ${ }^{\mathrm{TM}}$ PicoGreen ${ }^{\mathrm{TM}}$ dsDNA Assay Kit (Thermo Fisher Scientific, Darmstadt, Germany), respectively. The PhiX Control library (Illumina) was combined with the amplicon library (at 20\%). The library pool was clustered to a density of approximately $500-750 \mathrm{~K} / \mathrm{mm}^{2}$. The prepared libraries were sequenced on 300PE MiSeq runs. The resulting sequencing data matches the specifications when Q30average $>75 \%$. The image analysis, base calling, data quality assessment, and demultiplexing were performed on the MiSeq instrument. Utilizing the QIIME (V.1.8.0) software package, the sequences were quality trimmed (FASTQ) and paired-end aligned (PEAR). Taxonomic classification of the microbial communities was conducted by assigning the resulting sequences to operational taxonomic units (OTUs) using the USEARCH algorithm with a 97\% threshold of pairwise identity and classified taxonomically (species classifier RDP), referring to both the Greengenes database and the Human Intestinal Tract database (HITdb).

\section{References}

1. Wallen-Russell, C. The Role of Every-Day Cosmetics in Altering the Skin Microbiome: A Study Using Biodiversity. Cosmetics 2018, 6, 2. [CrossRef]

2. Kathuria, P.; Silverberg, J.I. Association of pollution and climate with atopic eczema in US children. Pediatr. Allergy Immunol. 2016, 27, 478-485. [CrossRef] [PubMed]

3. Patruno, C.; Nisticò, S.P.; Fabbrocini, G.; Napolitano, M. COVID-19, quarantine, and atopic dermatitis. Med. Hypotheses 2020, 143, 109852. [CrossRef] [PubMed]

4. Wallen-Russell, C.; Wallen-Russell, S. A new benchmark to determine what healthy western skin looks like in terms of biodiversity using standardised methodology. Cosmetics 2020, 7, 79. [CrossRef]

5. Marrs, T.; Flohr, C. The role of skin and gut microbiota in the development of atopic eczema. Br. J. Dermatol. 2016, 175, 13-18. [CrossRef]

6. Baviera, G.; Leoni, M.C.; Capra, L.; Cipriani, F.; Longo, G.; Maiello, N.; Ricci, G.; Galli, E. Microbiota in healthy skin and in atopic eczema. BioMed Res. Int. 2014, 2014, 436921. [CrossRef]

7. Wallen-Russell, C.; Wallen-Russell, S. Meta Analysis of Skin Microbiome: New Link between Skin Microbiota Diversity and Skin Health with Proposal to Use This as a Future Mechanism to Determine Whether Cosmetic Products Damage the Skin. Cosmetics 2017, 4, 14. [CrossRef]

8. Čelakovská, J.; Bukač, J. The severity of atopic dermatitis and analysis of the food hypersensitivity reactions. Food Agric. Immunol. 2015, 26, 896-908. [CrossRef]

9. Belkaid, Y.; Hand, T.W. Role of the microbiota in immunity and inflammation. Cell 2014, 157, 121-141. [CrossRef]

10. Zheng, D.; Liwinski, T.; Elinav, E. Interaction between microbiota and immunity in health and disease. Cell Res. 2020, 30, 492-506. [CrossRef] [PubMed]

11. Prescott, S.L.; Larcombe, D.-L.; Logan, A.C.; West, C.; Burks, W.; Caraballo, L.; Levin, M.; Van Etten, E.; Horwitz, P.; Kozyrskyj, A.; et al. The skin microbiome: Impact of modern environments on skin ecology, barrier integrity, and systemic immune programming. World Allergy Organ. J. 2017, 10, 29. [CrossRef] [PubMed]

12. Sanford, J.A.; Gallo, R.L. Functions of the skin microbiota in health and disease. Semin. Immunol. 2013, 25, 370-377. [CrossRef]

13. Castela, E.; Archier, E.; Devaux, S.; Gallini, A.; Aractingi, S.; Cribier, B.; Jullien, D.; Aubin, F.; Bachelez, H.; Joly, P.; et al. Topical corticosteroids in plaque psoriasis: A systematic review of efficacy and treatment modalities. J. Eur. Acad. Dermatol. Venereol. 2012, 26, 36-46. [CrossRef]

14. Uva, L.; Miguel, D.; Pinheiro, C.; Antunes, J.; Cruz, D.; Ferreira, J.; Filipe, P. Mechanisms of action of topical corticosteroids in psoriasis. Int. J. Endocrinol. 2012, 2012, 561018. [CrossRef]

15. Hengge, U.R.; Ruzicka, T.; Schwartz, R.A.; Cork, M.J. Adverse effects of topical glucocorticosteroids. J. Am. Acad. Dermatol. 2006, 54, 1-15. [CrossRef] 
16. Wu, L.T.; Zhu, H.; Ghitza, U.E. Multicomorbidity of chronic diseases and substance use disorders and their association with hospitalization: Results from electronic health records data. Drug Alcohol Depend. 2018, 192, 316-323. [CrossRef] [PubMed]

17. Ventola, C.L. The antibiotic resistance crisis: Causes and threats. Pharm. Ther. 2015, 40, 277-283.

18. Drake, L.A.; Dinehart, S.M.; Farmer, E.R.; Goltz, R.W.; Graham, G.F.; Hordinsky, M.K.; Lewis, C.W.; Pariser, D.M.; Webster, S.B.; Whitaker, D.C.; et al. Guidelines of care for the use of topical glucocorticosteroids. J. Am. Acad. Dermatol. 1996, 35, 615-619.

19. Ference, J.D.; Last, A.R. Choosing Topical Corticosteroids. Am. Fam. Physician 2009, 79, 135-140.

20. Juhasz, M.L.W.; Curley, R.A.; Rasmussen, A.; Malakouti, M.; Silverberg, N.; Jacob, S.E. Systematic Review of the Topical Steroid Addiction and Topical Steroid Withdrawal Phenomenon in Children Diagnosed With Atopic Dermatitis and Treated with Topical Corticosteroids. J. Dermatol. Nurses. Assoc. 2017, 9, 241-242. [CrossRef]

21. Hajar, T.; Leshem, Y.A.; Hanifin, J.M.; Nedorost, S.T.; Lio, P.A.; Paller, A.S.; Block, J.; Simpson, E.L. A systematic review of topical corticosteroid withdrawal ("steroid addiction") in patients with atopic dermatitis and other dermatoses. J. Am. Acad. Dermatol. 2015, 72, 541-549.e2. [CrossRef] [PubMed]

22. Coondoo, A.; Phiske, M.; Verma, S.; Lahiri, K. Side-effects of topical steroids: A long overdue revisit. Indian Dermatol. Online J. 2014, 5, 416. [CrossRef]

23. Sheary, B. Steroid Withdrawal Effects Following Long-term Topical Corticosteroid Use. Dermatitis 2018, 29 , 213-218. [CrossRef] [PubMed]

24. Ghosh, A.; Sengupta, S.; Coondoo, A.; Jana, A.K. Topical corticosteroid addiction and phobia. Indian J. Dermatol. 2014, 59, 465-468. [CrossRef]

25. Rathi, S.; D'Souza, P. Rational and ethical use of topical corticosteroids based on safety and efficacy. Indian J. Dermatol. 2012, 57, 251-259. [CrossRef] [PubMed]

26. Sheary, B. Topical steroid withdrawal: A case series of 10 children. Acta Derm. Venereol. 2019, 99, 551-556. [CrossRef] [PubMed]

27. Fukaya, M.; Sato, K.; Sato, M.; Kimata, H.; Fujisawa, S.; Dozono, H.; Yoshizawa, J.; Minaguchi, S. Topical steroid addiction in atopic dermatitis. Drug. Healthc. Patient Saf. 2014, 6, 131-138. [CrossRef]

28. Fasano, A. Zonulin, regulation of tight junctions, and autoimmune diseases. Ann. N. Y. Acad. Sci. 2012, 1258, 25. [CrossRef]

29. Valdes, A.M.; Walter, J.; Segal, E.; Spector, T.D. Role of the gut microbiota in nutrition and health. BMJ 2018, 361, 36-44. [CrossRef]

30. Finlay, B.B.; Arrieta, M.-C. Let Them Eat Dirt. Saving Your Child from an Oversanitized World; Windmill Books: London, UK, 2016.

31. Lefcheck, J.S.; Byrnes, J.E.K.; Isbell, F.; Gamfeldt, L.; Griffin, J.N.; Eisenhauer, N.; Hensel, M.J.S.; Hector, A.; Cardinale, B.J.; Duffy, J.E. Biodiversity enhances ecosystem multifunctionality across trophic levels and habitats. Nat. Commun. 2015, 6, 6936. [CrossRef]

32. Balvanera, P.; Pfisterer, A.B.; Buchmann, N.; He, J.-S.; Nakashizuka, T.; Raffaelli, D.; Schmid, B. Quantifying the evidence for biodiversity effects on ecosystem functioning and services. Ecol. Lett. 2006, 9, 1146-1156. [CrossRef] [PubMed]

33. Gamfeldt, L.; Hillebrand, H.; Jonsson, P.R. Multiple functions increase the importance of biodiversity for overall ecosystem functioning. Ecology 2008, 89, 1223-1231. [CrossRef]

34. Thrupp, L.A. The importance of biodiversity in agroecosystems. J. Crop Improv. 2004, 12, 315-337. [CrossRef]

35. Hooper, D.U.; Chapin, F.S.; Ewel, J.J.; Hector, A.; Inchausti, P.; Lavorel, S.; Lawton, J.H.; Lodge, D.M.; Loreau, M.; Naeem, S.; et al. Effects of biodiversity on ecosystem functioning: A consensus of current knowledge. Ecol. Monogr. 2005, 75, 3-35. [CrossRef]

36. Wallen-Russell, C. Is There a Relationship between Transepidermal Water Loss and Microbial Biodiversity on the Skin? Cosmetics 2019, 6, 18. [CrossRef]

37. De Filippo, C.; Cavalieri, D.; Di Paola, M.; Ramazzotti, M.; Poullet, J.B.; Massart, S.; Collini, S.; Pieraccini, G.; Lionetti, P. Impact of diet in shaping gut microbiota revealed by a comparative study in children from Europe and rural Africa. Proc. Natl. Acad. Sci. USA 2010, 107, 14691-14696. [CrossRef]

38. Wallen-Russell, C.; Wallen-Russell, S. Topical Probiotics Do Not Satisfy New Criteria for Effective Use Due to Insufficient Skin Microbiome Knowledge. Cosmetics 2021, 8, 90. [CrossRef]

39. Mukaka, M.M. Statistics corner: A guide to appropriate use of correlation coefficient in medical research. Malawi Med. J. 2012, 24, 69-71.

40. Lee Rodgers, J.; Nicewander, W.A. Thirteen Ways to Look at the Correlation Coefficient. Am. Stat. 1988, 42, 59-66. [CrossRef]

41. Sokal, R.R.; Rohlf, F.J. Biometry: The Principles and Practice of Statistics in Biological Research; W.H. Freeman and Co.: New York, NY, USA, 1995.

42. Weatherhead, S.; Robson, S.C.; Reynolds, N.J. Eczema in pregnancy. Br. Med. J. 2007, 335, 152-154. [CrossRef] [PubMed]

43. Sävervall, C.; Sand, F.L.; Thomsen, S.F. Dermatological diseases associated with pregnancy: Pemphigoid gestationis, polymorphic eruption of pregnancy, intrahepatic cholestasis of pregnancy, and atopic eruption of pregnancy. Dermatol. Res. Pract. 2015, 2015, 979635. [CrossRef] [PubMed]

44. Song, E.J.; Lee, J.A.; Park, J.J.; Kim, H.J.; Kim, N.S.; Byun, K.S.; Choi, G.S.; Moon, T.K. A study on seasonal variation of skin parameters in Korean males. Int. J. Cosmet. Sci. 2015, 37, 92-97. [CrossRef] [PubMed]

45. Qiu, H.; Long, X.; Ye, J.C.; Hou, J.; Senee, J.; Laurent, A.; Bazin, R.; Flament, F.; Adam, A.; Coutet, J.; et al. Influence of season on some skin properties: Winter vs. summer, as experienced by 354 Shanghaiese women of various ages. Int. J. Cosmet. Sci. 2011, 33, 377-383. [CrossRef] [PubMed]

46. Solomon, I.; Ilie, M.A.; Draghici, C.; Voiculescu, V.M.; Căruntu, C.; Boda, D.; Zurac, S. The impact of lifestyle factors on evolution of atopic dermatitis: An alternative approach (review). Exp. Ther. Med. 2019, 17, 1078-1084. [CrossRef] 
47. Fleischer, A.B. Atopic dermatitis: The relationship to temperature and seasonality in the United States. Int. J. Dermatol. 2019, 58, 465-471. [CrossRef] [PubMed]

48. Sheary, B.; Harris, M.F. Cessation of long-term topical steroids in adult atopic dermatitis: A prospective cohort study. Dermatitis 2020, 31, 316-320. [CrossRef] [PubMed]

49. Salem, I.; Ramser, A.; Isham, N.; Ghannoum, M.A. The gut microbiome as a major regulator of the gut-skin axis. Front. Microbiol. 2018, 9, 1459. [CrossRef]

50. Jung, G.W.; Tse, J.E.; Guiha, I.; Rao, J. Prospective, randomized, open-label trial comparing the safety, efficacy, and tolerability of an acne treatment regimen with and without a probiotic supplement and minocycline in subjects with mild to moderate acne. $J$. Cutan. Med. Surg. 2013, 17, 114-122. [CrossRef]

51. Fabbrocini, G.; Bertona, M.; Picazo, O.; Pareja-Galeano, H.; Monfrecola, G.; Emanuele, E. Supplementation with Lactobacillus rhamnosus SP1 normalises skin expression of genes implicated in insulin signalling and improves adult acne. Benef. Microbes 2016, 7, 625-630. [CrossRef]

52. Nosrati, A.; Afifi, L.; Danesh, M.J.; Lee, K.; Yan, D.; Beroukhim, K.; Ahn, R.; Liao, W. Dietary modifications in atopic dermatitis: Patient-reported outcomes. J. Dermatolog. Treat. 2017, 28, 523-538. [CrossRef]

53. Katta, R.; Schlichte, M. Diet and dermatitis: Food triggers. J. Clin. Aesthet. Dermatol. 2014, 7, 30-36. [PubMed]

54. Manasson, J.; Reddy, S.M.; Neimann, A.L.; Segal, L.N.; Scher, J.U. Cutaneous Microbiota Features Distinguish Psoriasis from Psoriatic Arthritis. Arthritis Rheumatol. 2016, 68. Available online: https://acrabstracts.org/abstract/cutaneous-microbiotafeatures-distinguish-psoriasis-from-psoriatic-arthritis/ (accessed on 18 July 2018).

55. Nakatsuji, T.; Chen, T.H.; Butcher, A.M.; Trzoss, L.L.; Nam, S.-J.; Shirakawa, K.T.; Zhou, W.; Oh, J.; Otto, M.; Fenical, W.; et al. A commensal strain of Staphylococcus epidermidis protects against skin neoplasia. Sci. Adv. 2018, 4, eaao4502. [CrossRef] [PubMed]

56. Zaidi, A.K.; Spaunhurst, K.; Sprockett, D.; Thomason, Y.; Mann, M.W.; Fu, P.; Ammons, C.; Gerstenblith, M.; Tuttle, M.S.; Popkin, D.L. Characterization of the facial microbiome in twins discordant for rosacea. Exp. Dermatol. 2018, 27, 295-298. [CrossRef] [PubMed]

57. Velegraki, A.; Cafarchia, C.; Gaitanis, G.; Iatta, R.; Boekhout, T. Malassezia Infections in Humans and Animals: Pathophysiology, Detection, and Treatment. PLoS Pathog. 2015, 11, e1004523. [CrossRef]

58. Huang, Y.J.; Marsland, B.J.; Bunyavanich, S.; O’Mahony, L.; Leung, D.Y.M.; Muraro, A.; Fleisher, T.A. The microbiome in allergic disease: Current understanding and future opportunities-2017 PRACTALL document of the American Academy of Allergy, Asthma \& Immunology and the European Academy of Allergy and Clinical Immunology. J. Allergy Clin. Immunol. 2017, 139, 1099-1110.

59. Sherwani, M.A.; Tufail, S.; Muzaffar, A.F.; Yusuf, N. The skin microbiome and immune system: Potential target for chemoprevention? Photodermatol. Photoimmunol. Photomed. 2018, 34, 25-34. [CrossRef] [PubMed]

60. Findley, K.; Oh, J.; Yang, J.; Conlan, S.; Deming, C.; Meyer, J.A.; Schoenfeld, D.; Nomicos, E.; Park, M.; Kong, H.H.; et al. Topographic diversity of fungal and bacterial communities in human skin. Nature 2013, 498, 367-370. [CrossRef] [PubMed]

61. Misic, A.M.; Gardner, S.E.; Grice, E.A. The Wound Microbiome: Modern Approaches to Examining the Role of Microorganisms in Impaired Chronic Wound Healing. Adv. Wound Care 2014, 3, 502-510. [CrossRef]

62. Gardiner, M.; Vicaretti, M.; Sparks, J.; Bansal, S.; Bush, S.; Liu, M.; Darling, A.; Harry, E.; Burke, C.M. A longitudinal study of the diabetic skin and wound microbiome. PeerJ 2017, 5, e3543. [CrossRef]

63. Salgado, V.R.; de Queiroz, A.T.L.; Sanabani, S.S.; de Oliveira, C.I.; Carvalho, E.M.; Costa, J.M.L.; Barral-Netto, M.; Barral, A. The microbiological signature of human cutaneous leishmaniasis lesions exhibits restricted bacterial diversity compared to healthy skin. Mem. Inst. Oswaldo Cruz 2016, 111, 241-251. [CrossRef] [PubMed]

64. Lu, L.J.; Liu, J. Human Microbiota and Ophthalmic Disease. Yale J. Biol. Med. 2016, 89, 325-330.

65. Kong, H.H.; Oh, J.; Deming, C.; Conlan, S.; Grice, E.A.; Beatson, M.A.; Nomicos, E.; Polley, E.C.; Komarow, H.D.; NISC Comparative Sequence Program; et al. Temporal shifts in the skin microbiome associated with disease flares and treatment in children with atopic dermatitis. Genome Res. 2012, 22, 850-859. [CrossRef]

66. Rocha, L.A.; Ferreira de Almeida e Borges, L.; Gontijo Filho, P.P. Changes in hands microbiota associated with skin damage because of hand hygiene procedures on the health care workers. Am. J. Infect. Control 2009, 37, 155-159. [CrossRef]

67. Blaser, M.J.; Falkow, S. What are the consequences of the disappearing human microbiota? Nat. Rev. Microbiol. 2009, 7, 887-894. [CrossRef]

68. Holland, K.T.; Bojar, R.A. Cosmetics: What is their influence on the skin microflora? Am. J. Clin. Dermatol. 2002, 3, 445-449. [CrossRef]

69. Costello, E.K.; Lauber, C.L.; Hamady, M.; Fierer, N.; Gordon, J.I.; Knight, R. Bacterial Community Variation in Human Body Habitats Across Space and Time. Science 2009, 326, 1694-1697. [CrossRef]

70. Cogen, A.L.; Nizet, V.; Gallo, R.L. Skin microbiota: A source of disease or defence? Br. J. Dermatol. 2009, 158, 442-455. [CrossRef]

71. Belkaid, Y.; Segre, J.A. Dialogue between skin microbiota and immunity. Science 2014, 346, 954-959. [CrossRef] [PubMed]

72. Stingley, R.L.; Zou, W.; Heinze, T.M.; Chen, H.; Cerniglia, C.E. Metabolism of azo dyes by human skin microbiota. J. Med. Microbiol. 2010, 59, 108-114. [CrossRef] [PubMed]

73. Turnbaugh, P.J.; Ley, R.E.; Hamady, M.; Fraser-Liggett, C.M.; Knight, R.; Gordon, J.I. The Human Microbiome Project. Nature 2007, 449, 804-810. [CrossRef] 
74. Staudinger, T.; Pipal, A.; Redl, B. Molecular analysis of the prevalent microbiota of human male and female forehead skin compared to forearm skin and the influence of make-up. J. Appl. Microbiol. 2011, 110, 1381-1389. [CrossRef]

75. Taylor, B.; Wadsworth, M.; Wadsworth, J.; Peckham, C. Changes in the reported prevalence of childhood eczema since the 1939-45 war. Lancet 1984, 324, 1255-1257. [CrossRef]

76. Simpson, C.R.; Newton, J.; Hippisley-Cox, J.; Sheikh, A. Trends in the epidemiology and prescribing of medication for eczema in England. J. R. Soc. Med. 2009, 102, 108-117. [CrossRef]

77. Burd, R.M. Psoriasis: A general overview. Br. J. Hosp. Med. 2006, 67, 259-262. [CrossRef] [PubMed]

78. Prescott, S.L.; Tang, M.L.K. The Australasian Society of Clinical Immunology and Allergy position statement: Summary of allergy prevention in children. Med. J. Aust. 2005, 182, 464-467. [CrossRef]

79. Srinivas, G.; Möller, S.; Wang, J.; Künzel, S.; Zillikens, D.; Baines, J.F.; Ibrahim, S.M. Genome-wide mapping of gene-microbiota interactions in susceptibility to autoimmune skin blistering. Nat. Commun. 2013, 4, 2462. [CrossRef]

80. Asher, M.I.; Montefort, S.; Björkstén, B.; Lai, C.K.; Strachan, D.P.; Weiland, S.K.; Williams, H.; ISAAC Phase Three Study Group. Worldwide time trends in the prevalence of symptoms of asthma, allergic rhinoconjunctivitis, and eczema in childhood: ISAAC Phases One and Three repeat multicountry cross-sectional surveys. Lancet 2006, 368, 733-743. [CrossRef]

81. Shaw, T.E.; Currie, G.P.; Koudelka, C.W.; Simpson, E.L. Eczema Prevalence in the United States: Data from the 2003 National Survey of Children's Health. J. Investig. Dermatol. 2011, 131, 67-73. [CrossRef] [PubMed]

82. Goossens, A. Contact-allergic reactions to cosmetics. J. Allergy 2011, 2011, 467071. [CrossRef]

83. Salverda, J.G.W.; Bragt, P.J.C.; de Wit-Bos, L.; Rustemeyer, T.; Coenraads, P.J.; Tupker, R.A.; Kunkeler, L.C.M.; Laheij-de Boer, A.-M.; Stenveld, H.J.; van Ginkel, C.J.W.; et al. Results of a cosmetovigilance survey in The Netherlands. Contact Dermat. 2013, $68,139-148$. [CrossRef]

84. Heisterberg, M.V.; Menné, T.; Johansen, J.D. Contact allergy to the 26 specific fragrance ingredients to be declared on cosmetic products in accordance with the EU cosmetics directive. Contact Dermat. 2011, 65, 266-275. [CrossRef] [PubMed]

85. Warshaw, E.M.; Buchholz, H.J.; Belsito, D.V.; Maibach, H.I.; Fowler, J.F.; Rietschel, R.L.; Zug, K.A.; Mathias, C.G.T.; Pratt, M.D.; Sasseville, D.; et al. Allergic patch test reactions associated with cosmetics: Retrospective analysis of cross-sectional data from the North American Contact Dermatitis Group, 2001-2004. J. Am. Acad. Dermatol. 2009, 60, 23-38. [CrossRef] [PubMed]

86. Berne, B.; Tammela, M.; Färm, G.; Inerot, A.; Lindberg, M. Can the reporting of adverse skin reactions to cosmetics be improved? A prospective clinical study using a structured protocol. Contact Dermat. 2008, 58, 223-227. [CrossRef] [PubMed]

87. Berne, B.; Boström, A.; Grahnén, A.F.; Tammela, M. Adverse effects of cosmetics and toiletries reported to the Swedish Medical Products Agency 1989-1994. Contact Dermat. 1996, 34, 359-362. [CrossRef]

88. Caruso, J.C.; Cliff, N. Empirical Size, Coverage, and Power of Confidence Intervals for Spearman's Rho. Educ. Psychol. Meas. 1997, 57, 637-654. [CrossRef]

89. Kim, H.-Y. Statistical notes for clinical researchers: Assessing normal distribution (2) using skewness and kurtosis. Restor. Dent. Endod. 2013, 38, 52-54. [CrossRef]

90. Mohd Razali, N.; Bee Wah, Y. Power comparisons of Shapiro-Wilk, Kolmogorov-Smirnov, Lilliefors and Anderson-Darling tests. J. Stat. Modeling Anal. 2011, 2, 21-23.

91. Shapiro, S.S.; Wilk, M.B. An Analysis of Variance Test for Normality (Complete Samples). Biometrika 1965, 52, 591. [CrossRef]

92. Brandwein, M.; Katz, I.; Katz, A.; Kohen, R. Beyond the gut: Skin microbiome compositional changes are associated with BMI. Hum. Microbiome J. 2019, 13, 100063. [CrossRef]

93. Ellis, S.R.; Nguyen, M.; Vaughn, A.R.; Notay, M.; Burney, W.A.; Sandhu, S.; Sivamani, R.K. The skin and gut microbiome and its role in common dermatologic conditions. Microorganisms 2019, 7, 550. [CrossRef] [PubMed]

94. De Pessemier, B.; Grine, L.; Debaere, M.; Maes, A.; Paetzold, B.; Callewaert, C. Gut-skin axis: Current knowledge of the interrelationship between microbial dysbiosis and skin conditions. Microorganisms 2021, 9, 353. [CrossRef] [PubMed]

95. Lack, G.; Fox, D.; Northstone, K.; Golding, J. Factors Associated with the Development of Peanut Allergy in Childhood. N. Engl. J. Med. 2003, 348, 977-985. [CrossRef] [PubMed]

96. BIOVIS. Intestinal Flora and Stool Diagnostics. Available online: https://www.biovis-diagnostik.eu/wp-content/uploads/ Intestinal-Flora-EN.pdf (accessed on 2 September 2021). 